Indexed by

\title{
Scopus
}

\section{MULTI-OBJECTIVE OPTIMIZATION OF TURNING PROCESS USING A COMBINATION OF TAGUCHI AND VIKOR METHODS}

\section{Nguyen Van Thien}

Hanoi University of Industry, Faculty of Mechanical Engineering, Hanoi city, Vietnam

\author{
Dung Hoang Tien \\ Hanoi University of Industry, \\ Faculty of Mechanical \\ Engineering, Hanoi city, \\ Vietnam
}

\author{
Do Duc Trung \\ Hanoi University of Industry, \\ Faculty of Mechanical \\ Engineering, Hanoi city, \\ Vietnam
}

KOBSON

\section{Nhu-Tung Nguyen}

Hanoi University of Industry, HaUI Institute of Technology HIT, Hanoi city, Vietnam

Key words: EN 10503 steel, surface roughness, cutting force, vibrations, multi-objective optimization, Taguchi, VIKOR

doi:10.5937/jaes0-29654

Cite article:

Thien Van N., Tien Hoang D., Trung Duc D., Nguyen N.T. (2021) MULTI-OBJECTIVE OPTIMIZATION OF TURNING PROCESS USING A COMBINATION OF TAGUCHI AND VIKOR METHODS, Journal of Applied Engineering Science, 19(4), 868 - 873, DOI:10.5937/ jaes0-29654

Online aceess of full paper is available at: www.engineeringscience.rs/browse-issues 


\title{
MULTI-OBJECTIVE OPTIMIZATION OF TURNING PROCESS USING A COMBINATION OF TAGUCHI AND VIKOR METHODS
}

\author{
Nguyen Van Thien ${ }^{1}$, Dung Hoang Tien ${ }^{1}$, Do Duc Trung ${ }^{1}$, Nhu-Tung Nguyen ${ }^{2 *}$ \\ ${ }^{1}$ Hanoi University of Industry, Faculty of Mechanical Engineering, Hanoi city, Vietnam \\ ${ }^{2}$ Hanoi University of Industry, HaUI Institute of Technology - HIT, Hanoi city, Vietnam
}

This study presents the solving process of the multi-objective optimization problem using VIKOR method when turning the EN 10503 steel. The cutting velocity, feed rate, depth of cut, and insert nose radius were chosen as the input parameters with three levels of each parameter. Taguchi L9 orthogonal array was used to design the experimental matrix with nine experiments. By the combination of Taguchi and VIKOR methods, the multi-objective optimization problem was successfully solved with optimal values (cutting velocity of $78.62 \mathrm{~m} / \mathrm{min}$, feed rate of $0.08 \mathrm{~mm} / \mathrm{rev}$, cutting depth of $0.5 \mathrm{~mm}$, and insert nose radius of $0.6 \mathrm{~mm}$. Using these the optimized input parameters, the surface roughness, cutting force and vibration component amplitudes (in $X, Y, Z$ directions), and material removal rate (MRR) were $0.621 \mu \mathrm{m}, 191.084 \mathrm{~N}, 51.727 \mathrm{~N}, 300.162 \mathrm{~N}, 4.465 \mu \mathrm{m}, 7.492 \mu \mathrm{m}, 10.118 \mu \mathrm{m}$, and $60.009 \mathrm{~mm} / \mathrm{s}$, respectively. This proposed method could be used to improve the quality and effectiveness of turning processes by improving the surface quality, reducing the cutting force and vibration amplitudes, and increasing the material removal rate.

Key words: EN 10503 steel, surface roughness, cutting force, vibrations, multi-objective optimization, Taguchi, VIKOR

\section{INTRODUCTION}

Turning is the most common machining process in the cutting methods. The work volume that is performed in turning processes is about $40 \%$ of the total workload of the machining processes. Besides, the number of turning machines is from $25 \%$ to $35 \%$ of the number of cutting machines in the cutting workshop [1].

The previous studies were conducted to reduce the machining surface roughness, cutting forces, and vibrations and to increase the MRR. To ensure the minimum value of surface roughness, Taguchi method was applied to obtain the optimal values of cutting velocity, feed rate, and depth of cut in the turning process of different materials such as aluminum [2], polyethylene [3], EN8 steel [4], EN 354 steel [5], AM alloy [6], unidirectional glass fiber reinforced plastics (UD-GFRP) [7], titanium alloy [8], Brass and Copper [9], medium carbon steel [10], Titanium Alloy Ti-6Al-4V [11], AISI 1020 steel [12], Aluminium-2014 Alloy [13], AISI 409 steel [14].

To ensure the maximum value of MRR, Taguchi was also applied in the determination of the cutting parameters in turning processes of thermoplastic polymer-delrin 500AL [15] and in turning processes of the unidirectional glass fiber reinforced plastic (UD-GFRP) composite16). Taguchi was also applied in the determination of the cutting parameters to ensure the minimum of cutting forces when machining some materials such as AM alloy [6], AISI 316L stainless steel [17], etc. Several studies applied the Taguchi method to optimize the turning process of different materials such as Aluminum Alloy AA6013 [18], Aluminum Alloy AA2024 [19], and EN25 steel [20].

So, the Taguchi method was successfully applied in optimizing the turning processes for different materials.
However, up to date, it seems that there have not been any studies that were performed to optimize the surface roughness, cutting forces, vibrations, and MRR in turning processes. VIKOR was a multi-objective optimization method that was applied in many different fields such as land management [21], Electrical Discharge Machine (EDM) [22, 23], milling process [24], etc. However, the studies that were performed to optimize the turning processes have not been mentioned. So, this study was performed to solve the multi-objective optimization problem in the turning process using Taguchi and VIKOR methods. The optimization problem was conducted with four input factors (machining velocity, feed rate, depth of cut, and insert nose radius) and with eight chosen evaluation criteria of the turning process (Surface roughness, three cutting force components in $X, Y, Z$ directions, three vibration components in $\mathrm{X}, \mathrm{Y}, \mathrm{Z}$ directions, and material removal rate).

Vikor method is a method of ranking priorities. The contents of this method is presented in the reference [25] as follows:

Assume that there are $i$ solutions $A=\left\{A_{i} \mid i=1,2,3, \ldots\right.$, $m\}$ and $j$ criterian $C=\left\{C_{j} \mid j=1,2,3, \ldots, n\right\}$; the evaluated value of solution $i$ to the criterion $j$ is $F=\{f i j \mid i=1,2,3$, $\ldots, m ; j=1,2,3, \ldots, n\} ; W$ is the weight of the criterian, $W=\left\{W_{j} \mid i=1,2, \ldots, m\right\}$. Then, the VIKOR decision matrix including four components was presented in Table 1.

The computational steps for ranking are presented as follows:

Step 1: Determining the best value $f^{*}$ and the worst value $f_{-j}$ of all criterian $C_{j}($ with $j=1,2, \ldots n$ ). 
Table 1: VIKOR decision matrix

\begin{tabular}{|c|c|c|c|c|c|c|}
\hline No. & $\mathrm{C}_{1}$ & $\mathrm{C}_{2}$ & $\ldots$ & $\mathrm{C}_{i}$ & $\ldots$ & $\mathrm{C}_{\mathrm{n}}$ \\
\hline $\mathrm{A}_{1}$ & $\mathrm{f}_{11}$ & $\mathrm{f}_{12}$ & $\ldots$ & $\mathrm{f}_{1 \mathrm{i}}$ & $\ldots$ & $\mathrm{f}_{1 \mathrm{n}}$ \\
\hline $\mathrm{A}_{2}$ & $\mathrm{f}_{21}$ & $\mathrm{f}_{22}$ & $\ldots$ & $\mathrm{f}_{2 \mathrm{i}}$ & $\ldots$ & $\mathrm{f}_{2 \mathrm{n}}$ \\
\hline$\ldots$ & $\ldots$ & $\ldots$ & $\ldots$ & $\ldots$ & $\ldots$ & $\ldots$ \\
\hline $\mathrm{A}_{\mathrm{n}}$ & $\mathrm{f}_{\mathrm{m} 1}$ & $\mathrm{f}_{\mathrm{m} 2}$ & $\ldots$ & $\mathrm{f}_{\mathrm{mi}}$ & $\ldots$ & $\mathrm{f}_{\mathrm{mn}}$ \\
\hline $\operatorname{Max}\left(\mathrm{f}_{\mathrm{i}}\right)$ & $\mathrm{f}_{1}^{*}$ & $\mathrm{f}^{*}{ }_{2}$ & $\ldots$ & $\mathrm{f}^{*}{ }_{i}$ & $\ldots$ & $\mathrm{f}^{*}$ \\
\hline $\operatorname{Min}\left(\mathrm{f}_{\mathrm{i}}\right)$ & $\mathrm{f}_{1}$ & $\mathrm{f}_{-}$ & $\ldots$ & $\mathrm{f}_{-}$ & $\ldots$ & $\mathrm{f}_{-}$ \\
\hline $\mathrm{W}$ & $\mathrm{w}_{1}$ & $\mathrm{w}_{2}$ & $\ldots$ & $\mathrm{w}_{\mathrm{i}}$ & $\ldots$ & $\mathrm{W}_{\mathrm{n}}$ \\
\hline
\end{tabular}

- If criterion $j$ is a positive criterion, $f_{j}^{*}=\max f_{i j}$ and $f_{-j}=\min f_{i j}$

- If criterion $j$ is not a positive criterion (bad criterion), $f_{j}^{*}=\min f_{i j}$ and $f_{-j}=\max f_{i j}$

Step 2: Standardizing the matrix and calculating $S_{i}, R_{i}$. Set: $r_{i j}=\left(\left|f^{*}{ }_{j}-f_{i j}\right|\right) /\left(\mid f^{*}{ }_{j}-f^{-}{ }_{j}\right)$

The value $S_{i}$ (the convenience) and $R_{i}$ (the separate regrets) were calculated by Eq. (3) and Eq (4).

$S_{i}=\sum_{j=1}^{n} w_{j}\left(\left|f_{j}^{*}-f_{i j}\right|\right) /\left(\left|f_{j}^{*}-f_{j}^{-}\right|\right)=\sum_{j=1}^{n} w_{j} r_{i j}$

$R_{i}=\max \left[w_{j}\left(\left|f_{j}^{*}-f_{i} j\right|\right) /\left(\left|f_{j}^{*}-f_{j}^{-}\right|\right)\right]=\max \left[w_{j} r_{i} j\right]$

Step 3: Calculating $Q_{i}$

The value $Q_{i}$ was calculated by Eq (5).

$Q_{i}=\frac{v\left(S_{i}-S^{*}\right)}{\left(\left(S^{-}-S^{*}\right)\right)}+(1-v)\left(R_{i}-R^{*}\right) /\left(R^{-}-R^{*}\right)$

with:

$0 \leq v \leq 1$

where:

$v$ is the weight of the positive criterion group. Normally, $v=0.5$ [25].

$1-v$ is the weight of the nonpositive criterion group.

And

$S^{*}=\min S_{i}$

$S^{-}=\max S_{i}$

$R^{*}=\min R_{i}$

$R^{-}=\max R$

Step 4: Ranking the solutions $A$ based on the values of $S_{i}, R_{i}, Q_{i}$ in order from small to large. The solution $A_{i}$ that has the smallest value of $Q_{i}$ is the best solution.

\section{MATERIAL AND METHOD}

\section{Experimental material}

In this study, the workpiece material was EN 10503 steel. This is common steel and is often used to manufacture the parts in machine manufacturers such as mechanical shafts, gears, mechanical levers, etc., because this steel has good machinability and low cost. According to several standards, the equivalent symbols of EN 10503 steel are presented in Table 2. Table 3 is the list of chemical compositions of EN 10503 steel. And Table 4 is the
Table 2: Equivalent symbols of EN 10503 steel

\begin{tabular}{|c|c|c|c|c|}
\hline Germany & United States & Europe & China & Japan \\
\hline DIN & SAE & EN & BS & JIS \\
\hline EN 10503 & 1045 & C45 & 060A4 & S45C \\
\hline
\end{tabular}

Table 3: Composition of EN 10503 steel

\begin{tabular}{|c|c|}
\hline Element & $\%$ \\
\hline $\mathrm{C}$ & 0.44 \\
\hline $\mathrm{Si}$ & 0.23 \\
\hline $\mathrm{Mn}$ & 0.65 \\
\hline $\mathrm{Cr}$ & 0.15 \\
\hline $\mathrm{Ni}$ & 0.15 \\
\hline $\mathrm{Mo}$ & 0.04 \\
\hline $\mathrm{V}$ & 0.01 \\
\hline $\mathrm{Ti}$ & 0.001 \\
\hline $\mathrm{B}$ & 0.0004 \\
\hline $\mathrm{Cu}$ & 0.21 \\
\hline
\end{tabular}

Table 4: Properties of EN 10503 steel

\begin{tabular}{|c|c|c|c|}
\hline $\begin{array}{c}\text { Young's } \\
\text { module } \\
(\mathrm{GPa})\end{array}$ & 210 & $\begin{array}{c}\text { Average CTE } 20-300^{\circ} \mathrm{C} \\
\left(\mu \mathrm{m} / \mathrm{m}^{\circ} \mathrm{K}\right)\end{array}$ & 12 \\
\hline $\begin{array}{c}\text { Pois- } \\
\text { son's } \\
\text { ratio }\end{array}$ & 0.3 & $\begin{array}{c}\text { Specific heat capacity } \\
50 / 100^{\circ} \mathrm{C}\left(\mathrm{J} / \mathrm{kg}^{\circ} \mathrm{K}\right)\end{array}$ & $460-480$ \\
\hline $\begin{array}{c}\text { Shear } \\
\text { module } \\
(\mathrm{GPa})\end{array}$ & 80 & $\begin{array}{c}\text { Thermal conductivity } \\
\text { Ambient temperature } \\
\left(\mathrm{W} / \mathrm{m}^{\circ} \mathrm{K}\right)\end{array}$ & $40-45$ \\
\hline $\begin{array}{c}\text { Density } \\
\left(\mathrm{kg} / \mathrm{m}^{3}\right)\end{array}$ & 7800 & $\begin{array}{c}\text { Electrical resistivity } \\
\text { Ambient temperature } \\
(\mu \Omega \mathrm{m})\end{array}$ & $0.20-0.25$ \\
\hline
\end{tabular}

list of the properties of EN 10503 steel. The length and diameter of the workpiece are $300 \mathrm{~mm}$ and $27.5 \mathrm{~mm}$, respectively, as shown in Fig 1.

\section{Turning machine and cutter}

The turning machine (FEL-1440GMW, MAGNUM-CUT, Taiwan) was used to conduct the experiments as shown in Fig 2. The inserts (Lungaloy, Japan) that were coated 


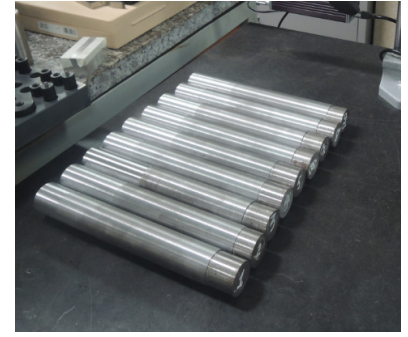

Figure 1: Workpieces in the experimental process

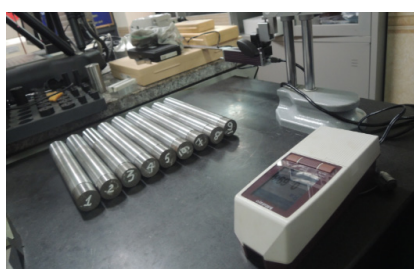

Figure 2: The setting of surface roughness measurement

with titanium were used in the experimental process with three nose radius $(0.4 \mathrm{~mm}, 0.6 \mathrm{~mm}$, and $1.2 \mathrm{~mm})$.

\section{Experimental design}

In this study, cutting velocity $(\mathrm{V})$ or workpiece speed $(\mathrm{n})$, feed rate (f), depth of cut (t), and insert nose radius ( $r$ ) were the input parameters. These parameters were chosen as the controllable factors, and the levels of each parameter were presented in Table 5 . Taguchi orthogonal array (L9) with 9 experiments was selected to design the experimental matrix as listed in Table 6.

Table 5: Input parameters and their levels

\begin{tabular}{|c|c|c|c|c|c|}
\hline \multirow{2}{*}{ Parameters } & \multirow{2}{*}{ Symbol } & Unit & \multicolumn{3}{|c|}{ Value at the level } \\
\cline { 4 - 6 } & & 1 & 2 & 3 \\
\hline $\begin{array}{c}\text { Workpiece } \\
\text { speed }\end{array}$ & $\mathrm{n}$ & $\mathrm{rev} / \mathrm{min}$ & 460 & 650 & 910 \\
\hline Feed rate & $\mathrm{f}$ & $\mathrm{mm} / \mathrm{rev}$ & 0.08 & 0.194 & 0.302 \\
\hline Depth of cut & $\mathrm{t}$ & $\mathrm{mm}$ & 0.15 & 0.30 & 0.45 \\
\hline $\begin{array}{c}\text { Insert nose } \\
\text { radius }\end{array}$ & $\mathrm{r}$ & $\mathrm{mm}$ & 0.4 & 0.6 & 1.2 \\
\hline
\end{tabular}

Table 6: Experimental matrix

\begin{tabular}{|c|c|c|c|c|c|c|c|c|}
\hline \multirow{2}{*}{ No. } & \multicolumn{3}{|c|}{ Coded value } & \multicolumn{5}{|c|}{ Actual value } \\
\cline { 2 - 9 } & $\mathrm{n}$ & $\mathrm{f}$ & $\mathrm{t}$ & $\mathrm{r}$ & $\mathrm{n}(\mathrm{rev} / \mathrm{min})$ & $\mathrm{f}(\mathrm{mm} / \mathrm{rev})$ & $\mathrm{t}(\mathrm{mm})$ & $\mathrm{r}(\mathrm{mm})$ \\
\hline 1 & 1 & 1 & 1 & 1 & 460 & 0.08 & 0.20 & 0.4 \\
\hline 2 & 1 & 2 & 2 & 2 & 460 & 0.194 & 0.35 & 0.6 \\
\hline 3 & 1 & 3 & 3 & 3 & 460 & 0.302 & 0.50 & 1.2 \\
\hline 4 & 2 & 2 & 3 & 3 & 650 & 0.08 & 0.35 & 1.2 \\
\hline 5 & 2 & 3 & 1 & 1 & 650 & 0.194 & 0.50 & 0.4 \\
\hline 6 & 2 & 1 & 2 & 2 & 650 & 0.302 & 0.20 & 0.6 \\
\hline 7 & 3 & 3 & 2 & 2 & 910 & 0.08 & 0.50 & 0.6 \\
\hline 8 & 3 & 1 & 3 & 3 & 910 & 0.194 & 0.20 & 1.2 \\
\hline 9 & 3 & 2 & 1 & 1 & 910 & 0.302 & 0.35 & 0.4 \\
\hline
\end{tabular}

\section{Measurement system}

The surface roughness of the machined parts was measured by Mytutoyo SJ-210 tester (Japan) as described in Fig 2. For all surface roughness measurements, the standard length was fixed at $0.8 \mathrm{~mm}$. For each measurement, the tool tip was moved parallel to the feed direction. The surface roughness was measured by repeating three times for each experiment.

Cutting force components in $\mathrm{X}, \mathrm{Y}$, and $\mathrm{Z}$ directions were measured using a cutting force measurement system, including a dynamometer (Kistler type 9139AA: force ranges: $(-3 K N \div 3 \mathrm{KN})$, a data processing system, and a Laptop with DynoWare software as described in Fig. 3.

The vibrations of the machining system were measured by a system including a three dimentions acceleration sensor (type 4525-B-001), a data processing system, and the PLUSE software as illustrated in Fig. 3. The acceleration sensor is mounted at the shell of the center of the turning machine. The system vibrations were measured simultaneously in $\mathrm{X}, \mathrm{Y}$, and $\mathrm{Z}$ directions.

The material removal rate (MRR) was calculated by Eq (10).

$$
M R R=\frac{1}{60}{ }^{*} n^{*} \pi^{*} d^{*} f^{\star} t\left(\mathrm{~mm}^{3} / \mathrm{s}\right)
$$
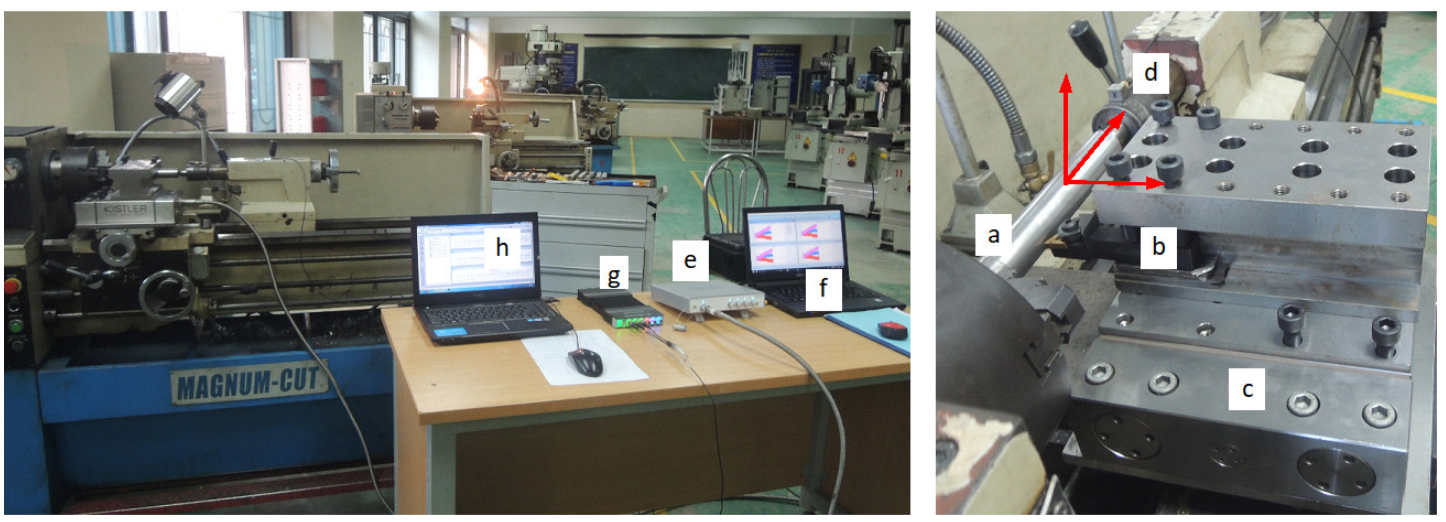

a. Workpiece b. Tool c. Dynamomster d. Acceleration sensor e. Cutting force signal processing system f. Laptop and DynoWare software g. Acceleration signal processing system $h$. PLUSE software

Figure 3: Cutting force and vibration measurement system 
Table 7: Experimental results

\begin{tabular}{|c|c|c|c|c|c|c|c|c|}
\hline No. & $\mathrm{R}_{a}(\mu \mathrm{m})$ & $\mathrm{F}_{x}(\mathrm{~N})$ & $\mathrm{F}_{\mathrm{v}}(\mathrm{N})$ & $\mathrm{F}_{z}(\mathrm{~N})$ & $\mathrm{A}_{x}(\mu \mathrm{m})$ & $\mathrm{A}_{v}(\mu \mathrm{m})$ & $\mathrm{A}_{z}(\mu \mathrm{m})$ & $\mathrm{MRR}\left(\mathrm{mm}^{3} / \mathrm{s}\right)$ \\
\hline 1 & 0.840 & 85.2740 & 24.9800 & 107.4400 & 2.3850 & 5.3594 & 5.5826 & 7.948 \\
\hline 2 & 0.605 & 166.2340 & 47.5420 & 230.3210 & 3.9816 & 8.5019 & 9.0195 & 54.471 \\
\hline 3 & 0.644 & 563.7300 & 153.2850 & 965.2270 & 5.9601 & 12.1603 & 16.2276 & 178.071 \\
\hline 4 & 1.122 & 219.2030 & 64.0220 & 335.7370 & 5.9392 & 8.8440 & 13.9882 & 57.823 \\
\hline 5 & 0.669 & 152.2660 & 38.5830 & 191.5410 & 4.3123 & 7.6545 & 9.3600 & 42.398 \\
\hline 6 & 0.643 & 175.3230 & 44.1470 & 211.6830 & 5.0853 & 9.9639 & 12.5087 & 31.447 \\
\hline 7 & 0.621 & 191.0840 & 51.7270 & 300.1620 & 4.4647 & 7.4923 & 10.1177 & 60.009 \\
\hline 8 & 0.729 & 212.9260 & 59.1170 & 307.8790 & 5.8284 & 8.4602 & 14.1956 & 33.694 \\
\hline 9 & 0.675 & 124.9690 & 40.5450 & 164.2060 & 6.2633 & 10.1637 & 15.2682 & 38.130 \\
\hline
\end{tabular}

where:

$\mathrm{n}$ is the workpiece speed (rev/min).

$\mathrm{d}$ is the workpiece diameter $(\mathrm{mm})$.

$f$ is the feed rate $(\mathrm{mm} / \mathrm{rev})$.

$t$ is the depth of cut $(\mathrm{mm})$.

\section{RESULTS AND DISCUSSION}

\section{Evaluation of experimental results}

After performing the experiments in the Table 6, The results were obtained and listed in Table 7 . The results in this Table show that it is difficult to determine the experiment, which simultaneously has the minimum value of surface roughness, minimum values of all three cutting force components, minimum values of all three vibration components, and the maximum of MRR.

It can be concluded that because with the results in Table 7 , the value of surface roughness was the smallest value (equal to $0.605 \mu \mathrm{m}$ ) in experiment number 2, but the values of all three cutting force components and all three vibration components were the smallest values in experiment number 1. Besides, MRR was the largest value in experiment number 3 .
From above analysis showed that it is not possible to choose one experiment from 9 performed experiments to simultaneously ensure the minimum value of surface roughness, the minimum values of cutting force components, the minimum values of vibration components, and the maximum value of MRR. Then, solving the multi-objective optimization problem is necessary to determine the cutting parameters and insert nose radius with small surface roughness, small cutting force components, small vibration component, and large MRR.

\section{Multi-objective optimization using VIKOR method}

To facilitate the use of the mathematical symbols in the optimization process, the surface roughness, cutting force amplitudes AFx, AFy, AFz, system vibration amplitudes $A x, A y, A z$, and MRR criteria were set as $C_{1}, C_{2}, C_{3}$, $\mathrm{C}_{4}, \mathrm{C}_{5}, \mathrm{C}_{6}, \mathrm{C}_{7}$, and $\mathrm{C}_{8}$ as presented in Table 8.

The calculated results of $r_{i j}$ (with $i=1 \div 16 ; j=1 \div 2$ ) according to the Eq. (2) were listed in Table 9.

The calculated results of $\mathrm{Si}, \mathrm{Ri}$ và $\mathrm{Qi}$ according to the Eq. (3) to Eq. (9) were listed in Table 10. The calculated results from Table 10 showed that solution $A_{7}$ had the smallest value of $Q_{7}$. So, this solution was the best solution in 9 solutions.

Table 8: VIKOR decision matrix for the turning process of EN 10503 steel

\begin{tabular}{|c|c|c|c|c|c|c|c|c|}
\hline & $\mathrm{C}_{1}$ & $\mathrm{C}_{2}$ & $\mathrm{C}_{3}$ & $\mathrm{C}_{4}$ & $\mathrm{C}_{5}$ & $\mathrm{C}_{6}$ & $\mathrm{C}_{7}$ & $\mathrm{C}_{8}$ \\
\hline 1 & 0.840 & 85.2740 & 24.9800 & 107.4400 & 2.3850 & 5.3594 & 5.5826 & 7.948 \\
\hline 2 & 0.605 & 166.2340 & 47.5420 & 230.3210 & 3.9816 & 8.5019 & 9.0195 & 54.471 \\
\hline 3 & 0.644 & 563.7300 & 153.2850 & 965.2270 & 5.9601 & 12.1603 & 16.2276 & 178.071 \\
\hline 4 & 1.122 & 219.2030 & 64.0220 & 335.7370 & 5.9392 & 8.8440 & 13.9882 & 57.823 \\
\hline 5 & 0.669 & 152.2660 & 38.5830 & 191.5410 & 4.3123 & 7.6545 & 9.3600 & 42.398 \\
\hline 6 & 0.643 & 175.3230 & 44.1470 & 211.6830 & 5.0853 & 9.9639 & 12.5087 & 31.447 \\
\hline 7 & 0.621 & 191.0840 & 51.7270 & 300.1620 & 4.4647 & 7.4923 & 10.1177 & 60.009 \\
\hline 8 & 0.729 & 212.9260 & 59.1170 & 307.8790 & 5.8284 & 8.4602 & 14.1956 & 33.694 \\
\hline 9 & 0.675 & 124.9690 & 40.5450 & 164.2060 & 6.2633 & 10.1637 & 15.2682 & 38.130 \\
\hline $\operatorname{Max}\left(\mathrm{f}_{\mathrm{i}}\right)$ & 1.122 & 563.73 & 153.285 & 965.227 & 6.2633 & 12.1603 & 16.2276 & 178.071 \\
\hline $\operatorname{Min}\left(\mathrm{f}_{\mathrm{i}}\right)$ & 0.605 & 85.274 & 24.98 & 107.44 & 2.385 & 5.3594 & 5.5826 & 7.948 \\
\hline
\end{tabular}


Table 9: The calculated values of $r_{i j}$

\begin{tabular}{|c|c|c|c|c|c|c|c|c|}
\hline & $\mathrm{r}_{1}$ & $\mathrm{r}_{2}$ & $\mathrm{r}_{3}$ & $\mathrm{r}_{4}$ & $\mathrm{r}_{5}$ & $\mathrm{r}_{6}$ & $\mathrm{r}_{7}$ & $\mathrm{r}_{8}$ \\
\hline $\mathrm{A}_{1}$ & 0.45455 & 0.00000 & 0.00000 & 0.00000 & 0.00000 & 0.00000 & 0.00000 & 1.00000 \\
\hline $\mathrm{A}_{2}$ & 0.00000 & 0.16921 & 0.17585 & 0.14325 & 0.41168 & 0.46207 & 0.32287 & 0.72653 \\
\hline $\mathrm{A}_{3}$ & 0.07544 & 1.00000 & 1.00000 & 1.00000 & 0.92182 & 1.00000 & 1.00000 & 0.00000 \\
\hline $\mathrm{A}_{4}$ & 1.00000 & 0.27992 & 0.30429 & 0.26615 & 0.91643 & 0.51237 & 0.78963 & 0.70683 \\
\hline $\mathrm{A}_{5}$ & 0.12379 & 0.14002 & 0.10602 & 0.09804 & 0.49694 & 0.33747 & 0.35485 & 0.79750 \\
\hline $\mathrm{A}_{6}$ & 0.07350 & 0.18821 & 0.14939 & 0.12153 & 0.69626 & 0.67704 & 0.65064 & 0.86187 \\
\hline $\mathrm{A}_{7}$ & 0.03095 & 0.22115 & 0.20846 & 0.22467 & 0.53624 & 0.31362 & 0.42603 & 0.69398 \\
\hline $\mathrm{A}_{8}$ & 0.23985 & 0.26680 & 0.26606 & 0.23367 & 0.88786 & 0.45594 & 0.80911 & 0.84866 \\
\hline $\mathrm{A}_{9}$ & 0.13540 & 0.08296 & 0.12131 & 0.06618 & 1.00000 & 0.70642 & 0.90987 & 0.82259 \\
\hline
\end{tabular}

Table 10: Calculated values of $S_{i}, R_{i}$ and $Q_{i}$

\begin{tabular}{|c|c|c|c|}
\hline & $S_{i}$ & $R_{i}$ & $Q_{i}$ \\
\hline$A_{1}$ & 0.72727 & 0.50000 & 0.50000 \\
\hline$A_{2}$ & 1.20573 & 0.36327 & 0.15851 \\
\hline$A_{3}$ & 2.99863 & 0.50000 & 1.00000 \\
\hline$A_{4}$ & 2.38781 & 0.50000 & 0.86554 \\
\hline$A_{5}$ & 1.22732 & 0.39875 & 0.27921 \\
\hline$A_{6}$ & 1.70922 & 0.43094 & 0.49047 \\
\hline$A_{7}$ & 1.32755 & 0.34699 & 0.13214 \\
\hline$A_{8}$ & 2.00398 & 0.44393 & 0.59783 \\
\hline$A_{9}$ & 1.92237 & 0.50000 & 0.76308 \\
\hline
\end{tabular}

So, the optimized values of cutting velocity (or workpiece speed), feed rate, cutting depth, and insert nose radius were $76.82 \mathrm{~m} / \mathrm{min}$ (or $910 \mathrm{rev} / \mathrm{min}, 0.08 \mathrm{~mm} / \mathrm{rev}$, and 0.5 $\mathrm{mm}, 0.6 \mathrm{~mm}$, respectively. Use these values, the output parameters that were obtained were Ra of $0.621 \mu \mathrm{m}, \mathrm{Fx}$, Fy, Fz of $191.084 \mathrm{~N}, 51.728 \mathrm{~N}$, and 300.162N, respectively, Ax, Ay, Az of $4.465 \mu \mathrm{m}, 7.492 \mu \mathrm{m}$, and $10.118 \mu \mathrm{m}$, respectively, and MRR of $60.009 \mathrm{~mm}^{3} / \mathrm{s}$.

Using the proposed method in this study, the quality and effectiveness of turning processes can be improved by reducing the surface quality, reducing the cutting force amplitudes, reducing the vibration amplitudes, and increasing the material removal rate.

\section{CONCLUSION}

A new method that was proposed to solve the multi-objective optimization problem in the turning process of EN 10503 steel was presented in this study.

The conclusions of this study were drawn as follows:

- The multi-objective optimization problem was successfully solved using Taguchi and VIKOR methods in the external turning process of EN 10503 steel.

- By combining Taguchi and VIKOR methods, the optimal values of cutting velocity, feed rate, depth of cut, and insert nose radius were $78.62 \mathrm{~m} / \mathrm{min}, 0.08 \mathrm{~m} /$ rev, $0.5 \mathrm{~mm}$, and $0.4 \mathrm{~mm}$, respectively.

- Using these optimized input parameters, the output paramerters including Ra, Fx, Fy, Fz, Ax, Ay, Az, and
MRR that were obtained were $0.621 \mu \mathrm{m}, 191.084 \mathrm{~N}$, $51.727 \mathrm{~N}, 300.162 \mathrm{~N}, 4.465 \mu \mathrm{m}, 7.492 \mu \mathrm{m}, 10.118$ $\mu \mathrm{m}$, and $60.009 \mathrm{~mm}^{3} / \mathrm{s}$, respectively.

By using proposed method in this study, the quality and effectiveness of turning processes can be improved by improving the surface quality, reducing the cutting force and vibration amplitudes, and increasing the material removal rate.

\section{ACKNOWLEDGMENTS}

The authors thank Faculty of Mechanical Engineering, Hanoi University of Industry, to support the measurement system during the implementation of this study.

\section{REFERENCES}

1. Dich, T.V., Binh, N.T., Dat, N.T., Tiep, N.V., Viet, T.X. (2003). Manufacturing technology, Science and Technics Publishing House, Ha Noi.

2. Pankaj, K. S., Novel, K.S., \& Ankit, D. (2017). Optimization of cutting parameters by turning operation in lathe machine, International Journal of Mechanical and Production Engineering, Vol. 5, No. 11, (2017), 46-51.

3. Lazarević, D., Madić, M., Janković, P., Lazarević, A. (2012). Cutting Parameters Optimization for Surface Roughness in Turning Operation of Polyethylene (PE) Using Taguchi Method, Tribology in Industry, Vol. 34, No. 2, pp. 68-73.

4. Subhabrata, B., Sumon, K., Supratim, C., Arpita, C. (2017). Process parameter optimization in lathe turning operation to improve the surface roughness and reduce the cutting force using Taguchi method, International journal of innovations in engineering research and technology, Vol. 8, No. 8, pp. 1-8.

5. Kajal, S., \& Yadav, S. (2015). Optimization of CNC turning parameters for surface roughness on EN 354 steel using Taguchi method. J Mater Sci Mech Eng, 2, pp.54-57. 
6. Dutta, S., \& Narala, S. K. R. (2021). Optimizing turning parameters in the machining of AM alloy using Taguchi methodology. Measurement, 169, 108340. doi: https://doi.org/10.1016/j.measurement.2020.108340

7. Gupta, M., \& Kumar, S. (2015). Investigation of surface roughness and MRR for turning of UD-GFRP using PCA and Taguchi method. Engineering Science and Technology, an International Journal, 18(1), 7081, doi: https://doi.org/10.1016/j.jestch.2014.09.006

8. Kechagias, J. D., Aslani, K. E., Fountas, N. A., Vaxevanidis, N. M., \& Manolakos, D. E. (2020). A comparative investigation of Taguchi and full factorial design for machinability prediction in turning of a titanium alloy. Measurement, 151, 107213, doi: https:// doi.org/10.1016/j.measurement.2019.107213.

9. Patod, S. K., \& Sharma, D. S. (2019). Optimization of CNC Turning Cutting Parameter for Geometrical Dimensional Accuracy with Surface roughness on the non-ferrous Material Applying Taguchi Technique. International Journal of Engineering Trends and Technology, 67(12), 56-66.

10. Mia, M., \& Dhar, N. R. (2017). Optimization of surface roughness and cutting temperature in high-pressure coolant-assisted hard turning using Taguchi method. The International Journal of Advanced Manufacturing Technology, 88(1-4), 739-753, doi: https://doi. org/10.1007/s00170-016-8810-2.

11. S. P. Shahebrahimi, S.P., Dadvand, A. (2013). Optimization of Cutting Parameters for Turning Operation of Titanium Alloy Ti-6Al-4V Material Workpiece using the Taguchi Method, Advanced Materials Research, 685, 57-62

12. Sonowal, D., Sarma, D., Barua, P. B., \& Nath, T. (2017). Taguchi optimization of cutting parameters in turning AISI 1020 MS with M2 HSS Tool. In IOP Conference Series: Materials Science and Engineering, 225 (1), 012186. IOP Publishing, doi:10.1088/1757899X/225/1/012186.

13. Aswal, A., Jha, A., Tiwari, A., \& Modi, Y. K. (2019). CNC Turning Parameter Optimization for Surface Roughness of Aluminium-2014 Alloy Using Taguchi Methodology, Journal Européen des Systèmes Automatisés, 52 (4), 387-390, doi: https://doi. org/10.18280/jesa.520408.

14. ÖZDEMIR, M. (2019). Optimization with Taguchi method of influences on surface roughness of cutting parameters in CNC turning processing. Mechanics, 25(5), 397-405, doi: https://doi.org/10.5755/ j01.mech.25.5.23005.

15. Upletawala, M. A. I., \& Katratwar, T. (2016). Optimization of Cutting Parameters for Turning Operation on Thermoplastic Polymer-Delrin 500AL. International Journal of Innovative Research in Science, Engineering and Technology, 5(8), 15545 - 15553,
16. Meenu, G., Surinder, K. (2013). Multi-objective optimization of cutting parameters in turning using grey relational analysis, International Journal of Industrial Engineering Computations, 4, 547-558.

17. Basmaci, G. (2018). Optimization of machining parameters for the turning process of AISI $316 \mathrm{~L}$ stainless steel and Taguchi design. Acta Physica Polonica A, 134(1), 260-264.

18. Guvenc, M. A., Cakir, M., \& Mistikoglu, S. (2019). Experimental study on optimization of cutting parameters by using Taguchi method for tool vibration and surface roughness in dry turning of AA6013. In 10th International Symposium on Intelligent Manufacturing and Service Systems, pp. 1032-1040.

19. Vladimir, A.R., Ghorbani, S. (2013). Optimization of Surface Roughness and Vibration in Turning of Aluminum Alloy AA2024 Using Taguchi Technique, International Journal of Mechanical, Industrial Science and Engineering, 7(11), 869-878.

20. Singaravel, B., \& Selvaraj, T. (2016). Application of Taguchi method for optimization of parameters in turning operation. Journal for Manufacturing Science and Production, 16(3), 183-187., doi: 10.1515/jmsp2016-0004

21. Dinh, L.C. (2016). The integrated model of GIS and AHPVIKOR for evaluating sustainable land-use management. Science \& technology development, 19(4), 97-104 (in Vietnamese).

22. Gangil, M., \& Pradhan, M. K. (2018). Optimization the machining parameters by using VIKOR Method during EDM process of Titanium alloy. Materials Today: Proceedings, 5(2), 7486-7495, doi: https://doi. org/10.1016/j.matpr.2017.11.420.

23. Bhuyan, R., \& Routara, B. (2016). Optimization the machining parameters by using VIKOR and Entropy Weight method during EDM process of $\mathrm{Al}-18 \% \mathrm{SiCp}$ Metal matrix composite. Decision Science Letters, 5(2), 269-282, doi: 10.5267 / j.dsl.2015.11.00.

24. Kumar, G. V. A., Reddy, D. V. V., \& Nagaraju, N. (2018). Multi-Objective Optimization of End Milling Process Parameters in Machining of EN 31 Steel: Application of AHP Embedded with VIKOR and WASPAS Methods. i-Manager's Journal on Mechanical Engineering, 8(4), 39-46, doi: https://doi. org/10.26634/jme.8.4.14676.

25. Opricovic, S., Tzeng, G.H. (2004). Compromise solution by MCDM method: A comparative analysis of VIKOR and TOPSIS. European journal of operational research, 156, 445-455

Paper submitted: 01.12.2020.

Paper accepted: 06.04.2021.

This is an open access article distributed under the CC BY 4.0 terms and conditions. 